DEMOGRAPHIC RESEARCH

VOLUME 33, ARTICLE 5, PAGES 113-144

PUBLISHED 14 JULY 2015

http://www.demographic-research.org/Volumes/Vol33/5/

DOI: 10.4054/DemRes.2015.33.5

Research Article

\title{
Patterns and selectivities of urban/rural migration in Israel
}

\section{Uzi Rebhun}

David L. Brown

@ 2015Uzi Rebhun \& David L. Brown.

This open-access work is published under the terms of the Creative Commons Attribution NonCommercial License 2.0 Germany, which permits use, reproduction \& distribution in any medium for non-commercial purposes, provided the original author(s) and source are given credit.

See http://creativecommons.org/licenses/by-nc/2.0/de/ 


\section{Table of Contents}

$\begin{array}{lll}1 & \text { Introduction } & 114\end{array}$

$2 \quad$ Background $\quad 115$

3 Data, definitions, and research strategy 117

$\begin{array}{lll}3.1 & \text { Data } & 117\end{array}$

$\begin{array}{ll}3.2 & \text { Census divisions and definitions } \\ & 118\end{array}$

$4 \quad$ Urban/rural distribution and mobility $\quad 120$

$5 \quad$ Selectivities in rural/urban migration 123

$6 \quad$ Factors associated with internal migration in Israel $\quad 127$

6.1 Informed "guesses" for urban/rural migration in Israel 127

$\begin{array}{lll}6.2 & \text { Model specification } & 130\end{array}$

$\begin{array}{lll}6.3 & \text { Results of the analysis } & 131\end{array}$

$\begin{array}{lll}7 & \text { Discussion and conclusions } & 134\end{array}$

$8 \quad$ Acknowledgements 137

$\begin{array}{ll}\text { References } & 138\end{array}$

$\begin{array}{ll}\text { Appendix A } & 143\end{array}$ 


\title{
Patterns and selectivities of urban/rural migration in Israel
}

\author{
Uzi Rebhun ${ }^{1}$ \\ David L. Brown ${ }^{2}$
}

\begin{abstract}
BACKGROUND

Movement from one type of area to another attests to factors of distance, socioeconomic barriers, and heterogeneity. Movement between two localities of one type entails fewer and different types of changes.
\end{abstract}

\section{OBJECTIVE}

We examine urban-rural migration in Israel, a country that has experienced extensive development outside of its major cities.

\section{METHODS}

We first describe and compare the urban and rural migration patterns of Jews and nonJews. However, due to the small number of non-Jewish migrants in the 2008 census data set, the explanatory analysis focuses solely on Jews, probing the characteristics of migrants and non-migrants and differentiating among the former by whether migration is between urban and rural places, or among urban or rural areas.

\section{RESULTS}

Examination of migration over five years points to a strong tendency to change residence, often involving a change of residence type. Urban-rural migration emphasizes the importance of specific individual characteristics and reflects the impact of life course and sociodemographic characteristics. We found a favorable sociodemographic profile of persons who leave the city for rural places, and a somewhat less favorable profile of people who are likely to move in the opposite direction. Migrants who move within settlement types are also somewhat more highly selected than persons moving toward cities.

\footnotetext{
${ }^{1}$ Division of Jewish Demography \& Statistics, The A. Harman Institute of Contemporary Jewry, The Hebrew University of Jerusalem, Israel. E-Mail: uzi.rebhun@mail.huji.ac.il.

${ }^{2}$ Department of Development Sociology, Cornell University, Ithaca, New York, U.S.A.

E-Mail: dlb17@cornell.edu.
} 


\section{CONCLUSIONS}

Urban-rural population exchanges among Jews in Israel, while generally in accord with studies in other countries, tend to be less definite with respect to educational attainment and age.

\section{COMMENTS}

Regardless of these differences, urban-rural exchanges of Jewish population in Israel are not a random process.

\section{Introduction ${ }^{3}$}

Israel, like other more developed nations, is highly urbanized. In fact, as early as 1955 , some eight out of every ten people were concentrated in places with 2,000 or more persons. ${ }^{4}$ The urban share has risen to nine of every ten today. Hence, one might ask, why study urban-rural migration if only $10 \%$ of the nation's population lives in rural areas? The reason is because even with such high rate of urban population concentration, people still move in and out of such places, and the selectivities of these migration streams can change the composition of urban and rural populations, even if they have little effect on the sizes of urban and rural places or the overall level of urbanization.

Older persons are less likely to move, for example, but those who do move are highly likely to seek rural destinations, thereby aging the rural population (Brown and Glasgow 2008). By contrast, people with advanced education and high professional qualifications are more likely to move from rural areas to cities, which offer better economic opportunities, higher returns on human capital, and cultural activities (Anderson 2011; Lichter and Brown 2011). Other research shows that some persons in later middle age, especially those with intact marriages and relatively high incomes, tend to move from cities to rural areas largely for lifestyle reasons (Champion and Sheppard 2006). Such selectivities alter the socioeconomic profile of rural localities, given their smaller relative size.

A focus on rural areas in metropolitan society is justified for many reasons regardless of such areas' small share of a nation's overall population. As Kulcsar and Curtis (2012) indicate in the International Handbook of Rural Demography, rural areas

\footnotetext{
${ }^{3}$ Throughout this paper we use the term "migrants" to indicate mobility between localities, "non-migrants" are people who remain geographically stable or moved within a given locality. "Immigrants" are foreign born people who moved to Israel, and "emigrants" are people who left the country.

${ }^{4}$ The definition of urban in Israel is places with 2,000 or more persons.
} 
and their populations continue to matter in more developed and highly urbanized countries because while only containing a minority of the population, they often account for a majority of a nation's land, water, minerals, energy, and other natural resources; as well as large parts of a nation's infrastructure such as roads, bridges, pipelines, and of course most of its domestic food production. (Brown and Schafft 2011).

In this paper we examine internal population mobility in Israel between urban and rural areas, as well as movement among places within the respective categories. We are interested in learning if migrants with certain social and economic characteristics are more likely to move from urban to rural locations, rural to urban locations, or to circulate within the urban and rural categories themselves. Not surprisingly, the migration selectivity of the Jewish and non-Jewish populations is of interest to Israel, hence, the first part of our analysis examines differences in migration propensity and direction of migration between Jews and non-Jews. Thereafter, because of a lack of data on non-Jews, we narrow the focus to Jews alone, examining the determinants of internal migration, and how such determinants might differ between rural-urban vs. urban-rural streams and between rural-urban and within category moves. In our analysis we examine the impact of individual demographic and socioeconomic characteristics on the direction of migration. Despite being a small country with relatively short distances between places, Israel has experienced extensive development outside of its major cities. This has been accompanied by continuous population dispersion. Insight into the Israeli case, which to the best of our knowledge has not been investigated over the last several years, contributes to the empirical and theoretical literature on urban and rural migration and population redistribution in contemporary, industrialized countries.

\section{Background}

Since its establishment in 1948, Israel's governments have viewed population as an instrument for spatial planning and resettlement (Eisenstadt 1973; Newman 2000). In a country where agricultural workers account for only a small fraction of the labor force and the location of industries is not affected by the dispersion of natural resources, considerations of social, economic, and geopolitical factors as well as environmental preferences become major determinants of the desired pattern of population distribution (Brotskos 1973). The government offers meaningful economic incentives, especially in housing, job opportunities, and tax breaks, to influence the spatial distribution of population. These factors, together with variability in individual and family resources (money, education, and social networks) have shaped the country's settlement structure and its internal migration patterns (Goldscheider 2002). 
From an ideological perspective, Jewish nationalism emphasized the nation's "return to the land" and promoted the deurbanization of the Jewish population (Goldscheider 2002). Complemented by security considerations along with utopian economic and social visions, a major guiding principle of governmental policy and planning has been the de-concentration of the Jewish population to the national periphery (Cohen 1970; Kirschenbaum 1982). Special governmental preference was, and still is, given to increasing the share of Jews in the North and South of the country, largely comprising the Galilee and the Negev. This involves the consolidation of geopolitically important areas such as Jerusalem and strengthening "development towns": urban localities specially established to receive population and anchor regional development in these areas (Choshen 2008). Another governmental aim in distributing the Jewish population is to reinforce the nation's geopolitical borders. Since the ascent to power of the political right in the second half of the 1970s, increasing attempts have been made to intensify Jewish control over the disputed territories.

Clauses pertaining to population dispersion appear in the founding principles and platforms of all Israeli governments. Practical and quantitative expressions of these intentions surface in programs prepared by government authorities, especially the Ministry of Interior and Ministry of Finance, and in several master plans that forecast the size and spatial distribution of the nation's population. Some of these plans describe anticipated development without government intervention or a continuation of existing trends. Others introduce policy goals that take factors elsewhere in the country into account, for example decline of population along the sea shore (Sicron 2004). The government continues to attach great importance to the development of national peripheries as was made evident in 2005 by the establishment of the Ministry for the Development of the Negev and Galilee.

Given the country's small size (approximately 21,000 square kilometers) ${ }^{5}$, some of the peripheries may be regarded as middle or outer rings of metropolitan areas; hence, while officially rural, they are located within easy access of urban places and labor markets. Moreover, the Israeli government has put substantial effort and money into improving the nation's road and public transportation systems that allow easy and convenient commuting from peripheral to central locations. This improved accessibility is meant to diminish the often clashing considerations between dwelling security and economic opportunities. Moreover, as is true of many modern societies (Frey 1988), Israel has been experiencing a regional restructuring where new firms and economic centers, especially of high technology, are being established in intermediate hinterland areas that are growing faster than their metropolitan counterparts (Cromartie and Parker 2014; Champion and Sheppard 2006; Kandel and Brown 2006; Shefer, Frenkel, and Roper 2001).

\footnotetext{
${ }^{5}$ Approximately half of the land is under military control, hence off limits for dwelling (Sicron 2004: 203).
} 
What differentiates Israel from most other highly developed countries is that Israel has a formal spatial policy of population deconcentration, which in combination with its physical characteristics tends to enhance the likelihood of movement of people from urban to rural localities. Today's desire among young families for private houses and improved quality of life also strengthens the allure of rural localities (Newman 2000). Consider the case of the Kibbutz. This settlement type was originally based on ideological and practical egalitarianism; collective ownership of property, economic cooperation, and the production of agricultural and heavy industrial products. Today, however, the Kibbutz is undergoing intensive privatization that is attracting new members or nonmember residents who seek to reside in an established rural environment with intimate social and cultural relationships (Ben-Rafael and Topel 2004).

In contrast to Jews, Arab Israelis are severely limited in internal migration due to informal constraints including lack of accessible housing, limited economic networks, and discrimination (Goldscheider 2002). Indeed, the extent that the Arab population is growing in peripheral areas is largely attributable to natural increase rather than net internal migration. Hence, this significantly limits the regional redistribution of the Arab population (Sicron 2004). Moreover, the dwelling needs of the growing nonJewish population originating from natural increase are hindered at the local level by intergenerational residential sharing, additions to existing houses, and the expansion of villages (Khamaisi 2005).

\section{Data, definitions, and research strategy}

\subsection{Data}

The data utilized in this study are derived from the 2008 Israel Population Census. The Innovative Integrated Census Method was used, which combined data from administrative sources (mainly a population register) with sample data gathered from surveys, i.e., in census field work. The field work included two surveys: the first was conducted from December 2008 to February 2009, and included approximately 400,000 households; the second was a telephone survey carried out from March 2009 to July 2009 , to complete census information and was comprised of some 250,000 people. The data file that was made available for this study included information from both parts of the census.

To assess the determinants, rather than the consequences, of migration with the

greatest possible adequacy, we inserted information for beginning of migration period (2003) into our census file in regard to two major achieved (changing) characteristics: 
employment status and income. These data, obtained from National Insurance Institute (the Israel Social Security) were attributed to respondents in accordance with their ID number.

Our sample is restricted to Jewish and non-Jewish (e.g., Muslims, Christians, Druze) respondents aged 18 and over. Jews and non-Jews may exhibit unique patterns of migration due to different exposures of modernization, specific occupational structure that may be suited to urban or rural areas, and social discrimination that limits non-Jews' ability to purchase dwellings and settle in localities that have a strong Jewish presence. A further criterion for inclusion in the analysis was residency in Israel for five years prior to the census. We focus on one adult (aged 18 and over) from each household, rather than multiple adults, in order to eliminate the potential bias of interdependence in migration behavior (Kritz and Nogle 1994). This adult, the person with whom the census interview was conducted, is a member of the household and was at home when an enumerator visited the dwelling. If multiple members were at home, they were asked to choose one of their members whom they preferred as the interviewee. The application of these criteria yielded a sample of 291,322 respondents: 241,868 Jews (83.0\%), and 49,454 non-Jews (17.0\%).

\subsection{Census divisions and definitions}

Localities in Israel are distinguished between rural and urban; the cutoff point is 2,000 in population. The type of locality is not dependent on its economic nature (agricultural or not) or other attributes. In fact, the rural category is quite diverse. It includes different types of organization and status. A main dimension of difference is between localities (Moshavim, Collective Moshavim, and Kibbutzim) that exhibit a particular kind of economic cooperation among inhabitants in production, marketing, or consumption, and those institutional or community localities where such economic cooperation does not exist. To a large extent, localities that are characterized by economic cooperation are populated by Jews while institutional and community localities may be populated by Jews or non-Jews.

In the non-Jewish segment of Israel's population, mainly that of Muslims, many urban localities maintain traditional rural land use and economic patterns. Even if they undergo a process of population concentration, this has not resulted in their urbanization in a social and economic sense. Though the population of these villages may be increasing, density may be on the rise, and residential construction using modern technology has begun, these localities have not experienced the developmental processes of industrialization and modernization which are typically associated with urbanization and urbanism. These localities lack an industrial economic base and/or 
services. In fact, the economic dependence of these non-Jewish localities on Jewish localities for work, consumption and in governmental budgets has strengthened over time (Khamaisi 2005).

\section{Figure 1: Map of Israel}

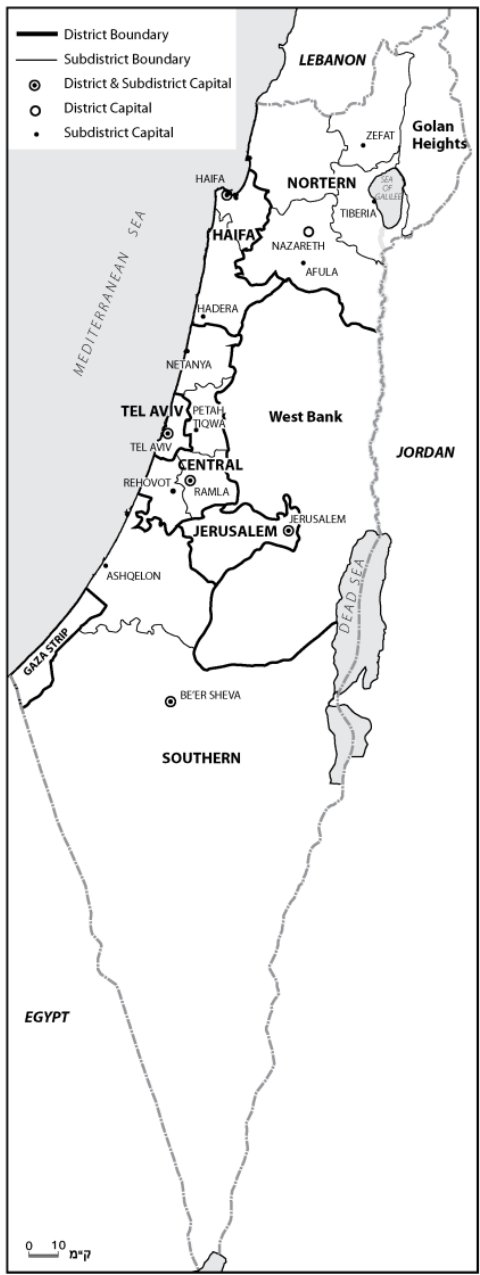

According to the 2008 Census, Israel had 1,178 localities: 229 urban and 949 rural. Each of the country's six official districts (see Map 1) were comprised of both urban 
and rural localities. ${ }^{6}$ The respective types of localities, however, are not evenly spread among the districts. Rural localities are disproportionately located in peripheral areas: the Northern District (332 localities) and the Southern District (209 localities). Nevertheless, a substantial number of rural localities, 187, may be found in the Central District. Tel Aviv is the only district that has more urban than rural localities.

The total number of localities also includes Jewish settlements in the disputed territories. During the period of our research, Israel withdrew unilaterally from the Gaza Strip and parts of the northern Samaria, removing 21 localities, most of which were rural. At the beginning of 2008, there were 119 Jewish settlements in the disputed territories, 27 urban and 92 rural. These 119 settlements are included in our study.

\section{Urban/rural distribution and mobility}

Israel's population is significantly urban and this characteristic has been increasing, though not consistently, over time. In 1955, shortly after statehood was attained, 83\% of Israelis lived in localities of 2,000 inhabitants or more. By 2008, the proportion had increased to $91.7 \%$ (Figure 2).

The Jewish community that was present upon statehood was already urban. During its formative years, even as substantial numbers from the massive influx of foreign born Jewish immigrants were directed to small settlements, many of these settlements quickly passed the 2,000 inhabitants threshold and became statistically, if not perceptually, "urban”. Many other Jewish immigrants settled in major cities such as Tel Aviv, Jerusalem, and Haifa. While in 1955 84.9\% of Jews lived in urban localities, it had increased to $90.3 \%$ by the early 1970 s and is at $90.8 \%$ today. In the meantime, the urbanized Jewish population has experienced suburbanization, with substantial movement from large urban cores to dormitory suburbs around major metropolitan areas (Goldscheider 1992). The non-Jewish population, in turn, has undergone rapid urbanization. The share of this population dwelling in localities with more than 2,000 inhabitants climbed from $63.5 \%$ in 1961 to $94.4 \%$ in 2008. Thus, the non-Jewish population today is slightly more urban than its Jewish counterpart.

\footnotetext{
6 "Districts" are regional agglomerations in Israel.
} 
Figure 2: Percentage of population in localities of 2,000 inhabitants or more. For selected years and by group affiliation

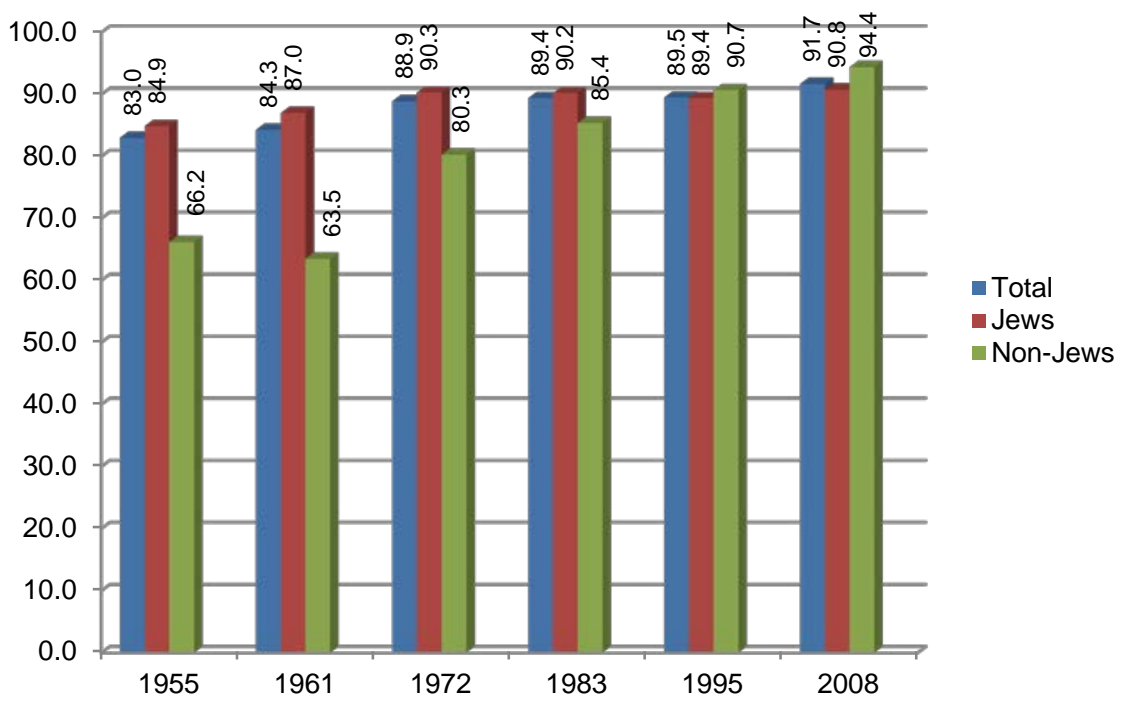

Source: CBS, Statistical Abstracts, various years.

The nation's increasing percentage of urban population is attributed to natural increase rather than to internal migration (and also possibly to international migration). Nevertheless, during the last two intercensal periods (1983-1995, and 1995-2008), there was a significant tendency of Jews to move from urban localities to agricultural and nonagricultural rural settlements. The annual population exchange by type of locality resulted in a net gain for rural localities during the 25 years between 1983 and 2008 (Figure 3). Within the fluctuation of this net gain, one interval is especially salient: the early 1990s, with its high migration surplus for rural areas. Accordingly, although the proportion of rural residents among Jews diminished (because urban areas grew more rapidly), the absolute number of Jewish rural residents increased impressively by more than 50\% (from 325,000 in 1983 to 508,000 in 2008) (Statistical Abstract of Israel, various years). Notably, some of this internal migration from city to rural locality, especially in northern Israel, is a "ruralization" process of sorts in which population leaps over major cities' suburbs into their more rural hinterland (Kirschenbaum 1992: 85). 
Figure 3: Net rural gain or loss from internal migration: Total population, Jews, and Non-Jews, 1978-2008

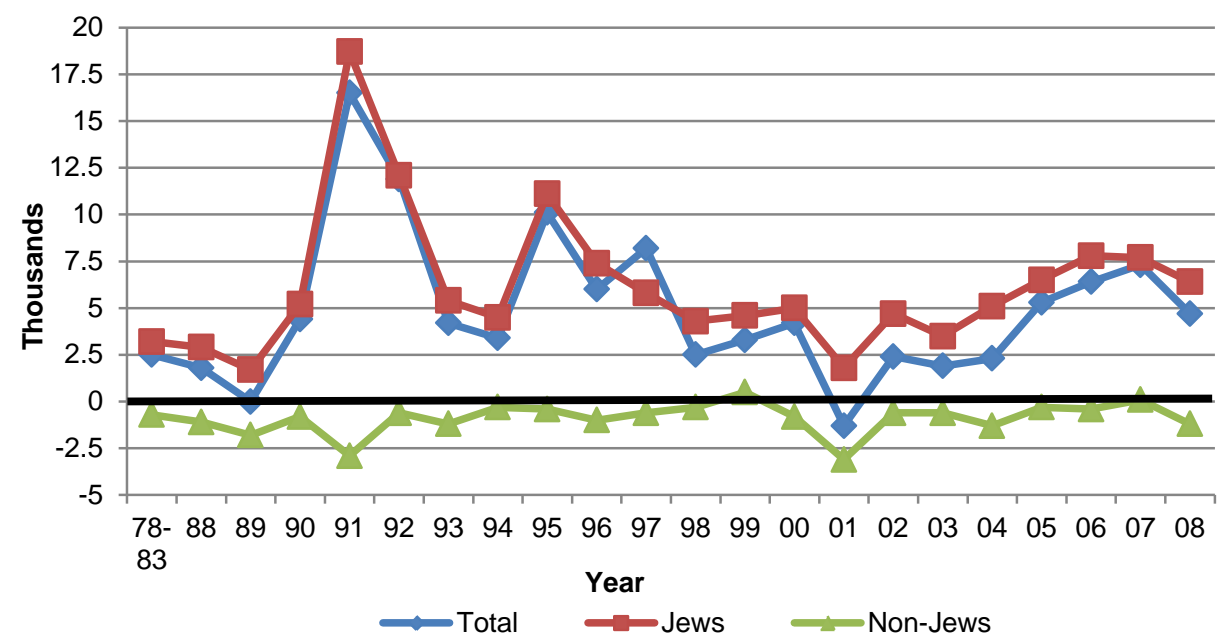

Sources: For 1978-1983: CBS, Internal migration, 1988; for 1988-2008: Statistical Abstracts, various years.

Among non-Jews, the data in Figures 2 and 3 show an increasing urban concentration, even though net exchanges between urban and rural areas have been small since 1983 (with the exception of two years with rather large net rural losses, 1991 and 2001, with the latter year resulting in a net rural loss for the total Israeli population) (Figure 3). Thus, the almost 10 percentage point increase in the level of urbanization that non-Jews have experienced since 1983 is associated mainly with natural increase and also, consequently, with changes in the status of localities from rural to urban even as the localities retain a population that is geographically quite stable.

Table 1 shows levels of migration for Jews and non-Jews using a fixed migration interval of five years. According to these data, between 2003 and 2008 some 14\% of Israelis changed their locality of residence, but the tendency to relocate to another locality was six times greater among Jews (16.2\%) than among non-Jews (2.8\%). 
Table 1: $\quad$ Five-year migration status among Jews and Non-Jews, 2003-2008: 2008 Israel census of housing and population (percentages)

\begin{tabular}{|c|c|c|c|c|c|c|c|c|c|c|}
\hline Religion & Total & (N) & Migration & n Status & & & & & & \\
\hline & & & $\begin{array}{c}\text { Same } \\
\text { Locality }^{\mathrm{a}}\end{array}$ & $\begin{array}{l}\text { Different } \\
\text { Locality }^{\mathrm{b}}\end{array}$ & Thereof: & $(\mathrm{N})$ & $\begin{array}{l}\text { Urban- } \\
\text { Urban }\end{array}$ & $\begin{array}{l}\text { Rural- } \\
\text { Rural }\end{array}$ & $\begin{array}{l}\text { Urban- } \\
\text { Rural }\end{array}$ & $\begin{array}{l}\text { Rural- } \\
\text { Urban }\end{array}$ \\
\hline Total & 100.0 & $(291,322)$ & 86.1 & 13.9 & 100.0 & $(40,417)$ & 67.4 & 7.6 & 17.1 & 7.9 \\
\hline Jews & 100.0 & $(241,868)$ & 83.8 & 16.2 & 100.0 & $(39,048)$ & 67.4 & 7.7 & 17.6 & 7.3 \\
\hline Non-Jews & 100.0 & $(49,454)$ & 97.2 & 2.8 & 100.0 & $(1,369)$ & 69.2 & 1.9 & 4.6 & 24.3 \\
\hline
\end{tabular}

a) Including same address, different address in the same locality, and unknown address in same locality.

b) Including different locality in same natural area, different natural area in same sub-district, and different sub-district.

Data from Table 1 also shows streams of internal migration in Israel. Among persons who moved between 2003 and 2008, 7.9\% moved from rural to urban areas, contributing to the country's further urbanization. In contrast, $17.1 \%$ moved from urban to rural areas contributing to population deconcentration. The remaining $75 \%$ of migrants moved within the urban and rural sectors; mostly among urban places. Jewish patterns of migration are reflected in these overall trends, while non-Jews are shown to be more likely to move from rural to urban areas, less likely to move from urban to rural, and slightly less likely to move within the urban or rural sectors. As migrants changed their place of residence, which could have possibly affected social relationships in the origin and destination communities, their migration did not significantly affect the nation's pattern of population distribution.

\section{Selectivities in rural/urban migration}

In this section we examine socioeconomic differences among migrants and nonmigrants and among the former by different types of migration. Given our focus on internal migration, the relative scarcity of non-Jewish migrants severely reduces the amount of data available on this population. Accordingly, in examining migration selectivity, we limit our attention to the Jewish population from this point forward. Our analysis seeks to evaluate social and economic correlates of migration between different types of localities as well as within similar categories of localities.

Migration across internal boundaries affects the relative sizes of places, and perhaps more importantly, their respective socioeconomic compositions. The long research tradition on urban-rural migration has emphasized differences between urban and rural communities, yet such sociodemographic and economic differences have substantially narrowed over time in highly developed and urbanized nations (Fuguitt, 
Brown, and Beale 1989; Fulton, Fuguitt, and Gibson 1997; Lacour and Puissant 2007; Warren 1987). For example, with the decline of employment in agriculture and other extractive industries, the economic activities of rural inhabitants and their urban counterparts have largely converged (Brown and Schafft 2011; Castle 1998), and new information and transport technologies have linked rural and urban people, communities, and economies ever more closely. The weakening of the urban-rural dichotomy is especially salient when levels of migration between these two types of localities are high (Champion and Hugo 2003). Hence, contemporary research on urban-rural migration in more developed nations such as Israel tends to emphasize the spatial integration that results from population mobility rather than spatial differentiation (Lichter and Brown 2011, 2014).

Many residents of rural localities commute to work in the city and, by doing so, maintain rural and urban orientations simultaneously (Brown et al. 1997). In fact, research indicates that urban to rural migrants are likely to retain their urban workplace at least for some time after moving (Champion, Coombes, and Brown 2009). Concurrently, rural areas have become places that city dwellers visit for recreation and to consume products and services (Green 2001). Even though the strengthening of interdependency and the convergence of different types of localities is likely to moderate the social and economic impacts of urban-rural migration (Brown et al. 1997), researchers still report that urban versus rural place of residency remains associated with persisting, albeit smaller, differences in people's sociodemographic attributes, behaviors and attitudes (Brown and Schafft 2011; Lichter and Brown 2011). Accordingly, we expect Israelis who move from urban to rural areas, the most likely intercategory migration stream, to differ in such characteristics compared with nonmigrants and with migrants who move from rural to urban areas. The data in Table 2 shows this to be the case. 
Table 2: Comparative profile of non-migrants and migrants: Israeli Jews, 2003-2008 (percentages)

\begin{tabular}{|c|c|c|c|c|c|c|c|}
\hline & \multirow[t]{2}{*}{ Total } & \multirow[t]{2}{*}{ Same Locality } & \multicolumn{5}{|c|}{ Different Locality } \\
\hline & & & Total & $\begin{array}{l}\text { Urban- } \\
\text { Urban }\end{array}$ & $\begin{array}{c}\text { Rural- } \\
\text { Rural }\end{array}$ & $\begin{array}{c}\text { Urban- } \\
\text { Rural }\end{array}$ & $\begin{array}{l}\text { Rural- } \\
\text { Urban }\end{array}$ \\
\hline$(\mathrm{N})$ & $(241,868)$ & $(202,820)$ & $(39,048)$ & $(26,304)$ & $(3,021)$ & $(6,866)$ & $(2,857)$ \\
\hline Age & 100.0 & 100.0 & 100.0 & 100.0 & 100.0 & 100.0 & 100.0 \\
\hline Age 25-34 & 19.7 & 13.2 & 53.2 & 54.2 & 44.6 & 51.2 & 58.7 \\
\hline Age $35-44$ & 20.2 & 19.6 & 23.2 & 20.6 & 30.4 & 30.1 & 22.6 \\
\hline Age $45-64$ & 37.9 & 42.1 & 16.3 & 16.1 & 22.7 & 14.7 & 14.7 \\
\hline Age 65+ & 22.2 & 25.1 & 7.3 & 9.1 & 2.3 & 4.0 & 4.0 \\
\hline Gender & 100.0 & 100.0 & 100.0 & 100.0 & 100.0 & 100.0 & 100.0 \\
\hline Male & 46.2 & 45.4 & 50.3 & 50.9 & 48.7 & 48.6 & 50.8 \\
\hline Female & 53.8 & 54.6 & 49.7 & 49.1 & 51.3 & 51.4 & 49.2 \\
\hline Marital Status & 100.0 & 100.0 & 100.0 & 100.0 & 100.0 & 100.0 & 100.0 \\
\hline Single & 10.6 & 7.9 & 24.7 & 25.6 & 20.7 & 20.2 & 31.8 \\
\hline Married & 66.4 & 67.7 & 59.7 & 57.5 & 66.3 & 68.2 & 52.7 \\
\hline Divorced/Separated & 12.4 & 12.6 & 11.8 & 12.4 & 11.3 & 9.2 & 13.2 \\
\hline Widowed & 10.6 & 11.9 & 3.7 & 4.5 & 1.8 & 2.4 & 2.4 \\
\hline Nativity & 100.0 & 100.0 & 100.0 & 100.0 & 100.0 & 100.0 & 100.0 \\
\hline Native-born & 56.2 & 52.5 & 75.2 & 70.7 & 84.2 & 84.8 & 83.7 \\
\hline Foreign-born 0-5 & 2.8 & 2.7 & 3.1 & 3.8 & 1.6 & 0.9 & 2.5 \\
\hline Foreign-born 6-10 & 6.2 & 6.6 & 4.5 & 5.7 & 2.3 & 1.8 & 2.7 \\
\hline Foreign-born 11+ & 34.8 & 38.2 & 17.2 & 19.8 & 11.8 & 12.5 & 11.0 \\
\hline Ethnicity & 100.0 & 100.0 & 100.0 & 100.0 & 100.0 & 100.0 & 100.0 \\
\hline Israeli & 15.2 & 12.4 & 30.0 & 27.5 & 34.3 & 33.7 & 39.0 \\
\hline Europe-America & 44.8 & 46.4 & 36.4 & 39.6 & 29.2 & 30.1 & 29.6 \\
\hline Asia-Africa & 40.0 & 41.3 & 33.6 & 32.9 & 36.5 & 36.2 & 31.4 \\
\hline Education & 100.0 & 100.0 & 100.0 & 100.0 & 100.0 & 100.0 & 100.0 \\
\hline 1-8 Years & 17.5 & 19.3 & 7.6 & 9.1 & 5.0 & 4.4 & 4.9 \\
\hline High school no matriculation & 18.1 & 19.0 & 13.2 & 13.0 & 14.9 & 13.6 & 12.6 \\
\hline High school with matriculation & 16.5 & 15.5 & 21.5 & 20.6 & 23.8 & 21.2 & 27.4 \\
\hline Vocational & 15.9 & 16.3 & 14.1 & 13.6 & 17.6 & 14.7 & 14.0 \\
\hline B.A. degree & 19.5 & 17.4 & 30.4 & 30.0 & 28.2 & 32.6 & 31.1 \\
\hline M.A. degree or higher & 12.6 & 12.5 & 13.1 & 13.7 & 10.5 & 13.4 & 10.0 \\
\hline Employment Status (in 2003) & 100.0 & 100.0 & 100.0 & 100.0 & 100.0 & 100.0 & 100.0 \\
\hline Employee & 57.8 & 55.8 & 68.0 & 67.5 & 66.6 & 71.5 & 66.0 \\
\hline Self-employed & 8.5 & 8.9 & 6.7 & 5.5 & 12.4 & 8.5 & 6.9 \\
\hline Don't work & 33.7 & 35.3 & 25.3 & 27.0 & 21.0 & 20.0 & 27.1 \\
\hline Income(in2003) & 100.0 & 100.0 & 100.0 & 100.0 & 100.0 & 100.0 & 100.0 \\
\hline Income quintile I & 20.0 & 18.3 & 27.6 & 27.9 & 26.4 & 25.5 & 31.2 \\
\hline Income quintile II & 20.0 & 19.3 & 23.0 & 23.0 & 24.1 & 23.0 & 21.8 \\
\hline Income quintile III & 20.0 & 20.1 & 19.4 & 19.1 & 20.8 & 20.4 & 18.0 \\
\hline Income quintile IV & 20.0 & 20.9 & 15.8 & 15.4 & 15.8 & 16.9 & 16.3 \\
\hline Income quintile $\mathrm{V}$ & 20.0 & 21.2 & 14.2 & 14.6 & 12.9 & 14.2 & 12.7 \\
\hline
\end{tabular}


These data indicate that migrants are younger, more likely to be male, and much more likely to be single than non-migrants. Similarly, migrants are much more likely to be native born of Israeli paternity. With respect to socioeconomic status, migrants exceed non-migrants in educational attainment, and are also more likely to be employed, but they are more concentrated in the lower income quintiles.

Migrants, of course, are not all cut from one cloth. There are often meaningful differences between migrants who move between urban and rural areas and those who move within the same residential classification. Comparing rural to urban migrants with their counterparts who move from urban to rural areas shows that the former are somewhat younger, slightly less likely to be female, much less likely to be married, more likely to be single or divorced, less likely to have a college education, to be employed, and to have slightly lower income prior to moving in 2003. In contrast, urban-rural migrants are more likely to be of foreign parentage and to work for others (Table 2).

Comparing the within category migrants with rural-urban migrants indicates that persons who move within rural are more likely to be middle age, married, and less likely to be either young adults or elderly. Rural to rural migrants are less likely to be of Israeli parentage, and more likely to be self-employed. Data on educational attainment shows few systematic differences between these two groups, but rural to rural migrants have somewhat higher incomes. Turning to persons who moved among urban places in comparison with rural to urban migrants shows them to less likely be young adults or early middle age and more likely to be elderly, more likely to be married, foreign born of European/American parentage, and to have graduate education. In addition, they had slightly higher incomes prior to moving in 2003. In contrast, they are less likely to be young adults, single, of Israeli parentage, and they are more likely to have the lowest levels of educational attainment.

It is difficult to summarize these differences in characteristics across the four migrant streams, although rural-urban migrants seem to be at an earlier stage of their life course and of somewhat lower socioeconomic status compared with urban persons who move to rural areas. Compared with urban-rural migrants people who moved from one rural place to another are middle aged, not married, and somewhat less well-off with respect to income prior to moving. Compared with urban-rural migrants, people who moved from one urban place to another are more likely to be elders, not married, foreign born, to have either the lowest or highest levels of educational attainment, and to have slightly higher incomes. These comparisons, and previous research on internal migration selectivities in more developed nations, lead us to focus our analysis on factors that affect the likelihood of migration in particular directions rather than others on three domains of individual level variables: (a) demographic characteristics, (b) life course status, and (c) socioeconomic attainments. 


\section{Factors associated with internal migration in Israel}

\subsection{Informed "guesses” for urban/rural migration in Israel}

The differences in characteristics across the various migration streams shown in Table 2 are simply bivariate comparisons. Will these differences between migration streams persist in a multivariate analysis? Our overall expectation, based on the internal migration literature and the foregoing descriptive comparisons, is that rural to urban migrants will be overrepresented by single persons in the young adult ages and will have a generally lower socioeconomic status than persons who move in the opposite direction. We also expect persons who circulate among urban or rural places to be more similar to urban-rural migrants than to persons moving up the settlement structure from rural areas to cities. It would seem that persons are moving to urban areas for economic opportunity. In contrast, rural in-migration will be among more maritally settled and better off persons who appear to be moving to enhance their amenities and quality of life. This would be consistent with research in other highly developed countries showing that even in today's less spatially differentiated societies, people continue to relocate from urban to rural or from rural to urban areas because of economic incentives and nonlabor market preferences associated with cultural patterns and amenities (Brown et al. 1997; Greenwood 1985; Zuiches 1980). The preference for a small or isolated residence over one's current urban location persists even if it results in some loss of income (Fuguitt and Brown 1990), attesting to a broader change: growing prioritization of consumption preferences over economic gains, known as the "clean break" theory (Vining and Strauss 1977). Moving farther from work places is facilitated by a trend toward longer distance commuting among rural persons, especially those who are recent migrants from urban areas (Champion, Coombes, and Brown 2009; Brown et al. 2015f). Likewise, Israel's small national geography would seem to facilitate migration without job transfer, and subsequent longer distance commuting.

The amenities and quality of life factors that attract mature people with a somewhat higher socioeconomic status to rural areas include low density (Wardwell 1980), relatively affordable private houses (Vining, Pallone, and Yang 1982), and a search for community of shared values and activities (Anderson 2011; Castle 1998). Migrants are also attracted to rural areas that have economies of their own, such as recreation and tourism. Moreover, some rural communities have become established as destinations for retirement age migrants (Brown et al. 2011; Brown and Glasgow 2008).

Aside from socioeconomic status, the literature indicates that migration is associated with a person's progression through the life course, and different types of moves are more probable at different life course stages. Life course stages are reflected in age and educational attainment, and where urban to rural migration is amenity 
motivated as we believe it is in Israel, we expect such moves to be undertaken by middle aged and employed persons who have completed their education. In contrast, motives of income enhancement would be expected of young adults who have not completed their higher education and who are more likely to be single.

Age would seem to have a clear association with the direction of migration: it is expected that younger migrants are more likely to move from rural to urban areas for economic, amenity, and cultural reasons. Typically, young adults prefer urban areas where high costs of living are countered by abundant educational, cultural, and employment opportunities. As people age, marry, and have children, their needs and preferences may change. Now they can be expected to ascribe greater importance to residential amenities, greater public safety, and schools which are often perceived to be superior in rural locations.

Retirees, typified by fixed pension and more leisure time "become increasingly interested in places where costs of living are low and amenities are high" (Domina 2006: 377). Those who have good pensions on top of Social Security may move to high amenity rural communities (Glasgow 1995; Johnson and Stewart 2011). However, migration rates are typically low at older ages. And in Israel, most homes for the elderly are located in major cities rather than in rural communities. Hence, while little geographic mobility is expected at older ages. To the extent that older persons move, we expect such migration to be from rural to urban or from urban to urban.

The direction of Jewish internal migration in Israel is also expected to be associated with immigration and ethnicity. Immigrants typically live in large cities where co-ethnic enclaves are located. In the US, there is evidence that some immigrants move beyond "gateway cities" to other urban and rural destinations (Kritz, Gurak, and Lee 2011). In addition, some immigrants move directly to rural communities (Crowley and Ebert 2014; Jensen 2006). New rural immigration in the US is linked to specific economic opportunities in food processing, agriculture, certain kinds of manufacturing, and service jobs (Jensen 2006; Kandel and Parrado 2005). As interesting as this may be, it is not directly relevant to the Israeli case. Israel lacks similar opportunities for immigrants in rural areas, hence migration from gateways to rural areas is not anticipated. To the extent that immigrants resettle internally, intra-urban moves would be expected.

This expectation is further supported by the urban origin of most immigrants to Israel. Most recent immigrants to Israel originated from the former Soviet Union, while smaller numbers came from North America, Western Europe, and South Africa (Statistical Abstract of Israel 2008). Like the overall Jewish population in these areas (DellaPergola 2008), the immigrants are significantly of urban background, from cities such as Moscow, Kiev, St. Petersburg, New York, London or Johannesburg. According to the last Soviet census (of 1989), for example, 98.7 percent of Soviet Jews were 
urbanites. Thus, we can be sure that the overwhelming majority of Soviet immigrants to Israel originated in cities and urban areas and not in rural localities. ${ }^{7}$ Similarly, the 2007 Pew Religious Landscape Survey revealed that, as of the enumeration date, 97.1 percent of American Jews resided in urban and suburban communities and only 2.9 percent in rural localities. ${ }^{8}$ At their time of arrival, these immigrants had human capital indicative of higher educational attainment than that of the nonimmigrant Israeli Jewish population, with large proportions concentrated in scientific, academic, and other white collar occupations (Sicron 1998; Rebhun and Waxman 2000). Notably, when the mass influx of Soviet Jews started in the early 1990s, and due to housing shortages, the government established mobile home camps, most of which were located in open spaces of rural jurisdictions. Those who tenanted these dwellings, however, left them upon the completion of many new apartments and encouragement from the government in urban areas, whether in the center or in the peripheries of the country.

In addition, in the past three decades Israel has absorbed some 100,000 immigrants from Ethiopia. This group is significantly different from those who arrived from North America and Europe due to their low levels of education, their widespread lack of professional qualifications, and their destitution (Kaplan and Salomon 2004). After initially settling them in special integration centers, mobile homes, hotels, and empty apartment blocks, the government initiated a special mortgage program for Ethiopian immigrants aimed at encouraging them to purchase apartments and establish permanent residence in relatively strong settlements in the center of the country. Even if some of them ended up in poor towns, they nevertheless settled in urban localities (Kaplan and Salomon 2004).

Hence, it came as something of a surprise to discover that 12 percent of the immigrants who arrived from 2002-2006 initially settled in rural localities (Central Bureau of Statistics 2009). Some of them probably came from North America and, due to their strong religious identification, chose to reside in small Jewish settlements in the disputed territories of the West Bank. A few others are Soviet immigrants of low economic status who could find cheap housing there (Gonen 1998). However, some three-fourths of immigrants who moved directly to rural localities first settled in Kibbutzim and Moshavim (cooperative settlements) within the recognized borders of the country. Most were young, in their twenties and thirties. An inquiry with the major organization responsible for immigrant absorption made it clear that most of these persons spent only five months at the Kibbutzim, during which they attended an

\footnotetext{
${ }^{7}$ The authors are grateful to Dr. Mark Tolts for providing us with this data, based on his own computation of the Statkomitet SNG, Itogi Vsesoiuznoi perepisi naseleniia 1989 goda (Results of the All-Union 1989 Census]. Minneapolis: East View Publications, 1993, Vol. 7, Part 1, table 2.

${ }^{8}$ Authors' analysis of data from the 2007 Pew Religious Landscape Survey.
} 
"Ulpan” (a Hebrew language program), meaning that they stayed there only temporarily.

Given that most immigrants came from cities and urban areas, they prefer similar types of localities in Israel. If they settled in places populated by non-immigrants while lacking command of the new language (Hebrew) and acquaintance with the local culture, immigrants would find their social adjustment somewhat difficult. Furthermore, permanent membership in rural localities, both veteran and new, involves an admission process that may be sticky and complicated for recent immigrants. Hence, the foreign born are less inclined than the native born to move from urban to rural localities. Although the strength of this relation weakens as time in Israel elapses, it remains negative.

As our literature review indicates, internal migration can be motivated by a variety of both economic and noneconomic reasons. In this section we examine the social and economic characteristics of migrants to, from, and within rural (and urban) Israel. We conduct a multivariate analysis to examine the impact of social and economic factors shown to be associated with migration in previous research on the likelihood of migration between urban and rural Israel, as well as migration within these residential categories.

We use multinomial logistic regression to compare the relative effect of various demographic and socioeconomic characteristics on the likelihood of being in particular migration streams relative to others. This will permit us to examine whether the comparisons shown in Table 2 persist when all of the attributes are considered together. We use the rural to urban migration stream as the reference because of its central role in urbanization, and we compare it with urban to rural migration, a principal demographic determinant of counter urbanization, and with migration among similar type places which has little or no impact on population distribution or on the composition of the urban or rural sector (although it can affect individual origin and destination places).

\subsection{Model specification}

To evaluate the robustness of the above "guesses", we applied a multinomial logistic regression. We organize the analysis into two models, each examining factors associated with being in a particular migration stream: urban to rural or among similar type localities, in comparison with being a rural to urban migrant. The first model includes all of the demographic, life course, and SES predictors other than income. It 
also includes a measure of migration distance, e.g., whether the migrant moved from one district to another. Model 2 includes all of these variables plus income. ${ }^{9}$

The explanatory variables follow those examined in the descriptive analysis as displayed in Table 2. Summary statistics of the dependent variables and explanatory variables are presented in Appendix A1. The basic migration model may be formulated as follows:

$$
\begin{gathered}
M i=a 0+a 1 A i+a 2 G i+a 3 S i+a 4 Y i+a 5 E i+a 6 D i+a 7 W i \\
+a 8 L i+a 9 I i+e i
\end{gathered}
$$

where $M_{\mathrm{i}}$, the dependent variable, is the log odds of making an urban to rural vs. rural to urban move/ between same type of localities vs. rural -to urban move, during the 2003-2008 period, i.e., $\log \left(\mathrm{M}_{i} / 1-\mathrm{M}_{i}\right)$, $a_{0}$ is the general mean, $a_{1} \ldots a_{9}$ are the estimated coefficients for the independent variables, and $e_{\mathrm{i}}$ is the residual, or predicted error, term.

The relationships between the independent variables and migration are presented as odds ratios (exp[b]) that expresses the relative odds of the occurrence of the event (migration) with a particular variable. Odds ratios less than 1.0 indicate that an explanatory variable is negatively associated with being an urban to rural migrant/within same type of locality rather than a rural to urban migrant, while an odds ratio of 1.0 or higher indicates the opposite (in a separate column we show probabilities that are easier to judge and interpret for readers who wish to compare the relative strength/importance of associations). Correct fit of the model is assessed through the likelihood of the observed results (translated into $-2 \log$ likelihood [-2LL]). Pseudo $\mathrm{R}^{2}$ (Nagelkerke $\mathrm{R}^{2}$ ) is a measure of the model's overall explanatory power.

\subsection{Results of the analysis}

The first analysis in Table 3 (column A) shows that compared with rural-urban migrants, Israelis who move from urban to rural areas are more likely to be married (compared with being single or divorced) and more likely to be born in Israel (especially in comparison with foreign born of short duration in their new country). In addition, urban-rural migrants are more likely to be of European-American or AsianAfrican extraction (first or second generation in the country).

\footnotetext{
${ }^{9}$ Information on income for the beginning of migration period (i.e., 2003) was available only for those who worked at that time. Accordingly, the multivariate analysis focuses solely on such persons distinguishing them between the employed and the self-employed.
} 
Rebhun \& Brown: Patterns and selectivities of urban/rural migration in Israel

Table 3: Multinomial logistic regression (Odds Ratios) and probabilities (B) of five-year migration from urban locality to rural locality and migration within similar types of localities (urban-to-urban and rural-to-rural) vs. migration from rural locality to urban locality on individual characteristics: Israeli Jews 2003-2008

\begin{tabular}{|c|c|c|c|c|c|c|c|c|}
\hline \multirow{3}{*}{ Independent Variables ${ }^{\mathfrak{D}}$} & \multicolumn{4}{|c|}{ Model 1} & \multicolumn{4}{|c|}{ Model 2} \\
\hline & \multicolumn{2}{|c|}{$\begin{array}{l}\text { Urban-Rural/ } \\
\text { Rural-Urban }(A)\end{array}$} & \multicolumn{2}{|c|}{$\begin{array}{l}\text { Same Localityl } \\
\text { Rural-Urban (B) }\end{array}$} & \multicolumn{2}{|c|}{$\begin{array}{c}\text { Urban-Rural/ } \\
\text { Rural-Urban (C) }\end{array}$} & \multicolumn{2}{|c|}{$\begin{array}{c}\text { Same Localityl } \\
\text { Rural-Urban (D) }\end{array}$} \\
\hline & $\begin{array}{l}\text { Odds Ratios } \\
\text { (S.E.) }\end{array}$ & B & $\begin{array}{l}\text { Odds Ratios } \\
\text { (S.E.) }\end{array}$ & B & $\begin{array}{l}\text { Odds Ratios } \\
\text { (S.E.) }\end{array}$ & B & $\begin{array}{l}\text { Odds Ratios } \\
\text { (S.E.) }\end{array}$ & B \\
\hline Age 25-34 & $\begin{array}{l}0.816 \\
(.225)\end{array}$ & -.204 & $\begin{array}{l}0.663^{\star} \\
(.199)\end{array}$ & -.411 & $\begin{array}{l}0.791 \\
(.226)\end{array}$ & -.235 & $\begin{array}{l}0.661^{\star} \\
(.200)\end{array}$ & -.413 \\
\hline Age $35-44$ & $\begin{array}{l}1.130 \\
(.225)\end{array}$ & .122 & $\begin{array}{l}0.665^{*} \\
(.199)\end{array}$ & -.409 & $\begin{array}{l}1.114 \\
(.225)\end{array}$ & .108 & $\begin{array}{l}0.653^{\star} \\
(.200)\end{array}$ & -.426 \\
\hline Age 45-64 & $\begin{array}{l}0.858 \\
(.223)\end{array}$ & -.153 & $\begin{array}{l}0.659^{\star} \\
(.197)\end{array}$ & -.418 & $\begin{array}{l}0.857 \\
(.224)\end{array}$ & -.155 & $\begin{array}{l}0.646^{\star} \\
(.198)\end{array}$ & -.437 \\
\hline Gender & $\begin{array}{l}1.028 \\
(.053)\end{array}$ & .028 & $\begin{array}{l}0.958 \\
(.048)\end{array}$ & -.043 & $\begin{array}{l}1.011 \\
(.055)\end{array}$ & .011 & $\begin{array}{l}0.965 \\
(.049)\end{array}$ & -.035 \\
\hline Marital status single & $\begin{array}{l}0.621^{\star \star \star} \\
(.064)\end{array}$ & -.477 & $\begin{array}{l}0.923 \\
(.056)\end{array}$ & -.080 & $\begin{array}{l}0.624^{\star \star \star} \\
(.065)\end{array}$ & -.471 & $\begin{array}{l}0.937 \\
(.057)\end{array}$ & -.065 \\
\hline $\begin{array}{l}\text { Marital status divorced/ } \\
\text { separated }\end{array}$ & $\begin{array}{l}0.522^{\star \star \star} \\
(.086)\end{array}$ & -.650 & $\begin{array}{l}0.737^{\star \star \star} \\
(.074)\end{array}$ & -.306 & $\begin{array}{l}0.522^{\star \star \star} \\
(.086)\end{array}$ & -.649 & $\begin{array}{l}0.740^{\star \star \star} \\
(.074)\end{array}$ & -.301 \\
\hline Marital status widowed & $\begin{array}{l}0.748 \\
(.264)\end{array}$ & -.291 & $\begin{array}{l}0.935 \\
(.231)\end{array}$ & -.067 & $\begin{array}{l}0.753 \\
(.264)\end{array}$ & -.284 & $\begin{array}{l}0.946 \\
(.231)\end{array}$ & -.056 \\
\hline Foreign born $0-5$ & $\begin{array}{l}0.415^{\star \star \star} \\
(.224)\end{array}$ & -.879 & $\begin{array}{l}1.451^{\star} \\
(.172)\end{array}$ & .372 & $\begin{array}{l}0.413^{\star \star \star} \\
(.225)\end{array}$ & -.885 & $\begin{array}{l}1.480^{*} \\
(.173)\end{array}$ & .392 \\
\hline Foreign born 6-10 & $\begin{array}{l}0.585^{\star \star} \\
(.185)\end{array}$ & -.536 & $\begin{array}{l}1.848^{\star \star \star} \\
(.151)\end{array}$ & .614 & $\begin{array}{l}0.578^{\star \star} \\
(.185)\end{array}$ & -.548 & $\begin{array}{l}1.856^{\star \star \star} \\
(.152)\end{array}$ & .618 \\
\hline Foreign born $11+$ & $\begin{array}{l}0.997 \\
(.097)\end{array}$ & -.003 & $\begin{array}{l}1.598^{\star \star \star} \\
(.086)\end{array}$ & .469 & $\begin{array}{l}0.997 \\
(.097)\end{array}$ & -.003 & $\begin{array}{l}1.603^{\star \star \star} \\
(.086)\end{array}$ & .472 \\
\hline Ethnicity Europe-America & $\begin{aligned} 1.164^{\star} \\
(.064)\end{aligned}$ & .152 & $\begin{array}{l}1.257^{\star \star \star} \\
(.058)\end{array}$ & .229 & $\begin{array}{l}1.157^{\star} \\
(.064)\end{array}$ & .146 & $\begin{array}{l}1.250 * * * \\
(.058)\end{array}$ & .223 \\
\hline Ethnicity Asia-Africa & $\begin{array}{l}1.206^{\star} \\
(.074)\end{array}$ & .187 & $\begin{array}{l}1.408^{\star \star \star} \\
(.066)\end{array}$ & .342 & $\begin{array}{l}1.204^{\star} \\
(.074)\end{array}$ & .186 & $\begin{array}{l}1.403^{\star \star \star} \\
(.066)\end{array}$ & .339 \\
\hline High school no matriculation & $\begin{array}{l}0.878 \\
(.166)\end{array}$ & -.130 & $\begin{array}{l}0.684^{\star \star} \\
(.146)\end{array}$ & -.380 & $\begin{array}{l}0.879 \\
(.166)\end{array}$ & -.130 & $\begin{array}{l}0.678^{\star} \\
(.146)\end{array}$ & -.389 \\
\hline $\begin{array}{l}\text { High school with } \\
\text { matriculation }\end{array}$ & $\begin{array}{l}0.924 \\
(.162)\end{array}$ & -.080 & $\begin{array}{l}0.672^{\star \star} \\
(.142)\end{array}$ & -.398 & $\begin{array}{l}0.932 \\
(.162)\end{array}$ & -.070 & $\begin{array}{l}0.665^{\star \star} \\
(.143)\end{array}$ & -.407 \\
\hline Vocational & $\begin{array}{l}0.912 \\
(.164)\end{array}$ & -.092 & $\begin{array}{l}0.649^{\star \star \star} \\
(.145)\end{array}$ & -.433 & $\begin{array}{l}0.922 \\
(.624)\end{array}$ & -.081 & $\begin{array}{l}0.643^{\star \star} \\
(.145)\end{array}$ & -.442 \\
\hline B. A. degree & $\begin{array}{l}0.972 \\
(.158)\end{array}$ & -.029 & $\begin{array}{l}0.689^{\star \star} \\
(.140)\end{array}$ & -.372 & $\begin{array}{l}0.993 \\
(.159)\end{array}$ & -.007 & $\begin{array}{l}0.682^{\star \star} \\
(.141)\end{array}$ & -.383 \\
\hline M.A. degree or higher & $\begin{array}{l}1.167 \\
(.168)\end{array}$ & .154 & $\begin{array}{l}0.855 \\
(.149)\end{array}$ & -.122 & $\begin{array}{l}1.204 \\
(.170)\end{array}$ & .185 & $\begin{array}{l}0.872 \\
(.151)\end{array}$ & -.137 \\
\hline $\begin{array}{l}\text { Employment status- } \\
\text { Self-employed }\end{array}$ & $\begin{array}{l}1.063 \\
(.091)\end{array}$ & .062 & $\begin{array}{l}0.875 \\
(.083)\end{array}$ & -.133 & $\begin{array}{l}1.045 \\
(.091)\end{array}$ & .044 & $\begin{array}{l}0.868 \\
(.083)\end{array}$ & -.141 \\
\hline $\begin{array}{l}\text { Migration status- } \\
\text { Different district }\end{array}$ & $\begin{array}{l}0.951 \\
(.053)\end{array}$ & -.050 & $\begin{array}{l}0.946 \\
(.047)\end{array}$ & -.055 & $\begin{array}{l}0.953 \\
(.053)\end{array}$ & -.048 & $\begin{array}{l}0.952 \\
(.047)\end{array}$ & -.049 \\
\hline
\end{tabular}


Table 3: (Continued)

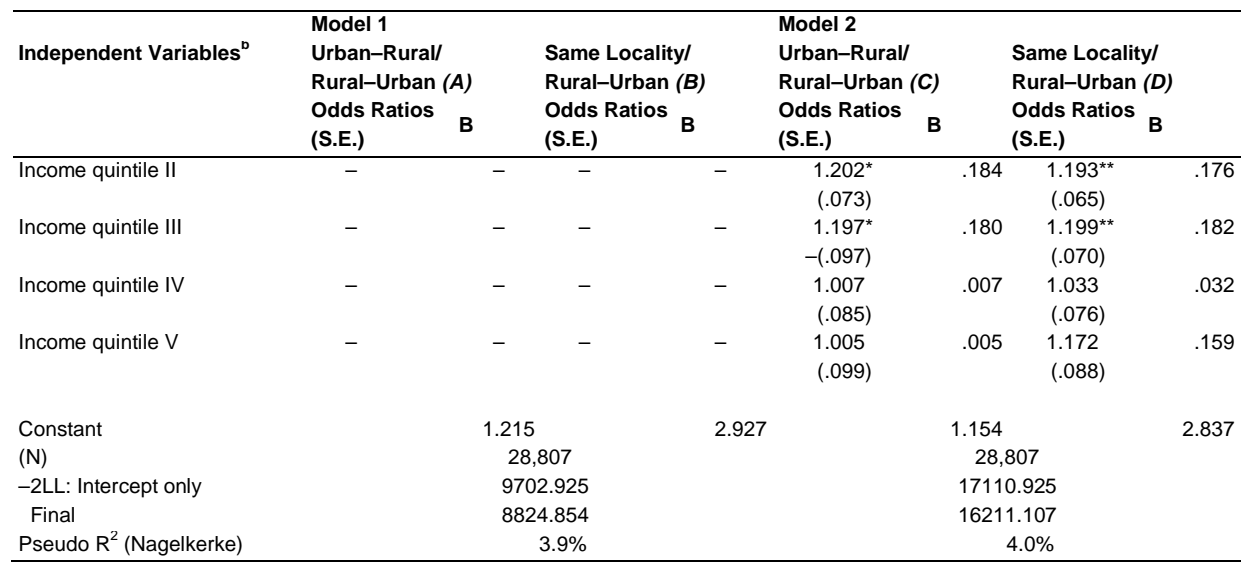

${ }^{\star} P<.05 ;{ }^{\star \star} P<.01 ; P<.001$

a) Numbers in parentheses are standard errors.

b) Reference categories are as follows: age - 65 years and over; gender - male; marital status-married; nativity - native born Israelis; ethnicity - Israeli; education - less than high school graduation; employment status - employee; migration status-same district; income - lowest quintile (0-19.9\%).

When income is added in model 2 (column C), the odds ratios suggest that urban to rural migrants have slightly higher incomes than persons who move from rural to urban areas, e.g., they are more likely to be in income quintiles II and III compared with the lowest quintile, but not more likely to be in the two highest income quintiles. The associations of marital status, nativity, and ethnicity remain unchanged. In contrast, age, educational attainment, migration distance, and employment status are not associated with being an urban-rural migrant rather than moving in the opposite direction.

Next we examine factors associated with migration among similar residence categories (urban-urban and rural-rural) vis-a-vis moving from a rural to an urban area. Compared with persons who arrived in urban destinations from rural origins, intracategory migrants are less likely to be younger than 65 years, and also less likely to be divorced rather than married (Table 3, column B). Within category migrants are more likely to be foreign born having arrived either recently or a decade ago, and of nonIsraeli ethnicity. In addition, intra-category migrants are less educated.

When income is added in model 2 (column D), it can be seen that intra-category migrants have notably higher incomes than persons who move from rural to urban areas, although most of the difference is in the middle of the income distribution. The impacts of age, marital status, nativity, ethnicity, educational attainment and employment status are unchanged when income is accounted for. Similarly, gender and 
migration distance remain unassociated with the likelihood of moving within the same residential categories in comparison with moving from rural to urban.

Comparing a model with no variables (intercept only) with a model with the independent variables (final) we find that the measure of error, -2LL, was reduced: from 9702.925 to 8824.854 in model 1 and from 17110.925 to 16211.107 in model 2.

\section{Discussion and conclusions}

This study examined the levels, directions, and determinants of urban-rural migration in Israel during 2003-08. The paper first examined the prevalence of urban-rural migration patterns among Jews and non-Jews, showing that Jews have been much more geographically mobile during 2003-08. Thereafter, due to a small number of nonJewish migrants, we focused solely on Jews comparing the demographic and socioeconomic characteristics of internal migrants vs. non-migrants, and among the latter according to various migration streams. The final part of the analysis used multivariate analysis to determine whether compositional differences shown in the comparative profile of various migration streams are associated with the likelihood of moving between and among various residence categories. In general, we find the bivariate comparisons to persist in the multivariate analysis. Persons who move to less urbanized settings tend to be married and of somewhat higher income compared with those who move in the opposite direction. Hence, moving to the countryside in Israel seems consistent with the amenity and life style migration process that is common elsewhere in postindustrial societies. As we indicated earlier in the paper, this is facilitated by the relatively short distances between rural residences and urban employment sites in Israel.

It stands to reason that some Israelis who have already attained high socioeconomic status as indicated by income may move from urban to rural localities to seek private houses in quiet and open surroundings. This is especially true given the short distances between Israel's rural localities and its urban labor centers where highly educated people lean toward rural localities that offer amenities and high quality of life. In contrast, migrants in the opposite (rural-to-urban) direction are expected to be less well-off than persons moving to rural communities. For example, they may include former members of Kibbutzim, whose cooperative socialist ideology prevented them from owning properties and amassing personal savings. Even though many Kibbutzim have undergone privatization and some of their members have joined the public sector as salaried workers, many lack the job longevity and official training that they need to compete with their urban counterparts, resulting in lower earnings. Others may be people of Asian/African background who arrived in Israel shortly after the foundation 
of the state, and were settled in agrarian rural localities. Typically, they belong to the low middle economic stratum, as do their adult offspring.

There are other incentives for moving to rural (or between) rural areas in Israel. In addition to notably lower average dwelling prices in rural localities (Calcalist 2010), the Israeli government offers significant economic incentives including convenient housing loans, discounts on land for homebuilding, and lower taxes to encourage people to settle in peripheral areas. However, with the exception of guest rooms or bed and breakfasts for side income, rural areas in Israel lack developed economic enterprises of their own. Indeed, most rural workers commute to urban workplaces. The mainstay of the Israeli rural employment, agriculture, is also diminishing over time. Accordingly, rural places are less attractive to younger, unmarried persons who are in their prime working ages.

However, while the residential preference vs. economic opportunity explanation is consistent with research conducted in the UK and elsewhere, it is somewhat speculative and should be examined through longitudinal analysis of the commuting behavior of urban-rural migrants (Brown et al. 2015f; Champion, Coombes, and Brown 2009). The availability of survey data on residential preferences and migration intentions would also contribute to a stronger case for the implied motivations of urban-rural migrants. In contrast to urban-rural migrants, persons who moved from rural to urban areas tend to have somewhat lower incomes and appear to be moving to cities in search of enhanced economic opportunities. Rural destinations also seem to be receiving migrants who, while Israeli natives, were born to non-Israeli parents. Hence, rural living may be an aspect of the assimilation process experienced by Israel's second generation. The internal migration processes shown in this research while not contributing much to population redistribution do affect the relative sociodemographic composition of rural and urban Israel.

Within-category migrants, e.g., persons who move from one urban place to another or from one rural area to another, are also somewhat compositionally distinct from rural-urban migrants. Similar to persons who decentralized their residences from urban to rural places, intra-category migrants are somewhat higher socioeconomic status compared with persons who made cityward moves. Moreover, they are less likely to be over the age of 65 since most elder housing in Israel is concentrated in cities. Intraurban and intra-rural migrants also differ in nativity and ethnicity compared with cityward migrants who are more likely to be both foreign born and to identify as having Israeli parentage.

Despite being a highly urban society, Israelis exhibit a relatively strong tendency to change their type of residence from urban to rural as well as in the reverse direction. In fact, almost one in five Israeli Jews changed residence during 2003-08 which is quite high compared with other highly developed nations (Molloy, Smith, and Wozniak 2011). Many of these movements are relatively short distance, but a substantial number 
are longer distance involving a change of district of residency. These patterns of urban/rural migration are not spread evenly among the population; rather certain sociodemographic characteristics differentiate among persons engaged in various streams of rural-urban movement.

Our analysis illuminated major aspects of the demographic interplay between urban and rural areas in Israel. We portray a favorable sociodemographic profile of persons who leave the city in favor of rural places, and a somewhat less favorable profile of people who are likely to move in the opposite direction. Moreover, in addition to migration between urban and rural areas, our data shows that migrants who move within settlement types, e.g., urban to urban or rural to rural, are also somewhat more highly selected than persons moving toward cities. Accordingly, while internal migration no longer contributes much to population redistribution in Israel because of its already high level of urbanization, it does have the ability to alter the compositions of populations living in various types of places. The general picture that is suggested in this analysis is of better off persons with intact families moving to rural areas for amenity and lifestyle reasons, while less well-off persons tend to look for better economic opportunities in cities. While elders have relatively low migration rates, those who do migrate tend to move to cities where elder housing opportunities are more available. This is in contrast to the older migration process in the US and other highly developed nations.

Research on urban-rural migration outside of Israel often shows well established selectivities with migration to urban areas being comprised of younger, more educated persons who are either single or newly married. Persons who move from urban to rural are also positively selected in terms of socioeconomic factors such as income and education, but they also tend to be older than persons who move to rural retirement destinations (Kulcsar and Curtis 2012). Urban-rural population exchanges among Jews in Israel which are generally in accord with previous studies of the phenomena in other countries, especially with respect to income selectivity, tend to be less definite with respect to educational attainment and age. Perhaps this is because many of the ruralurban moves in Israel are of relatively short distance and either originate or end in lower density, peripheral, e.g., rural parts of large urban agglomerations. Regardless of these differences, it is clear that rural-urban exchanges of Jewish population in Israel are not a random process. Persons who move within and between the rural and urban settlement categories are socioeconomically differentiated from each other, and among longer distance migrants, economic opportunities of the destination also affect migration probabilities ${ }^{10}$. Accordingly, while research on rural-urban migration elsewhere is a guide for such research in Israel, the Israeli situation tells its own story

\footnotetext{
${ }^{10}$ Data not shown here but available from the authors.
} 
which helps to elucidate the diversity of internal migration processes experienced by more developed nations.

Future research should re-analyze these models for the non-Jewish population. As indicated above, this was not possible with the census data due to the small number of migrants. Such an investigation will allow us to assess the effect of being part of the majority population (Jews) vs. the minority (non-Jews) with all other things being equal. This could shed light on processes of integration vs. separation thus expanding the contribution of this study beyond the demographic-geographic realm to better understand the spatial dimension of group belonging in contemporary Israel.

\section{Acknowledgements}

Earlier versions of this paper were presented at the following: European Society for Rural Sociology, Florence 29 July-August 1, 2013; the $7^{\text {th }}$ International Conference on Population Geographies, Groningen 25-28 June, 2014; European Population Conference, Budapest 25-28, June 2014; Population Association of America Annual Meeting, San Diego April 30-May 2, 2015 (poster). We wish to thank Nadia Beider for her assistance in copy editing; as well as two anonymous referees for especially helpful comments. Responsibility for the contents of the paper rests solely with the authors. 


\section{References}

Anderson, H.S. (2011). Explanations for long-distance counter-urban migration into fringe areas in Denmark. Population, Space and Place 17(5): 627-641. doi:10.1002/psp.568.

Ben-Rafael, E. and Topel, M. (2004). The Kibbutz's transformation: Who leads it and where?. In: Rebhun, U. and Waxman, C.I. (eds.). Jews in Israel: Contemporary social and cultural patterns. Hanover and London: Brandeis University Press/University Press of New England: 151-173.

Brotskos, A. (1973). A plan for the geographic dispersion of the population of Israel of 5 million. [in Hebrew]. City and Area 3: 3-25

Brown, D.L. and Glasgow, N. (2008). Rural retirement migration. Dordrecht, The Netherlands: Springer. doi:10.1007/978-1-4020-6895-9.

Brown, D.L., Bolender, B.C, Kulcsar, L.J., Glasgow, N., and Sanders, S. (2011). Intercounty variability of net migration at older ages as a path dependent process. Rural Sociology 76(1): 44-73. doi:10.1111/j.1549-0831.2010.00034.x.

Brown, D.L., Fuguitt, G.V., Heaton, T.B., and Waseem, S. (1997). Continuities in size of place preferences in the United States, 1972-1992. Rural Sociology 62(4): 408-428. doi:10.1111/j.1549-0831.1997.tb00657.x.

Brown, D.L. and Schafft, K.A. (2002). Population deconcentration in Hungary during the post-Socialist transformation. Journal of Rural Studies 18(3): 233-244. doi:10.1016/S0743-0167(01)00046-8.

Brown, D.L. and Schafft, K.A. (2011). Rural people and communities in the $21^{\text {st }}$ Century: Resilience and transformation. Cambridge: Polity Press.

Brown, D.L., Champion, T., Coombes, M., and Wymer, C. (2015f). Examining the Migration-Commuting Nexus in Rural England: A Longitudinal Analysis. Journal of Rural Studies 40.

Calcalist: A daily business newspaper. (.2010). Research: Price of a new villa in the Negev or in the Galilee worth half the price of an old three bedroom apartment in the Center. [in Hebrew].

Castle, E.N. (1998). A conceptual framework for the study of rural places. American Journal of Agriculture Economy 80(3): 621-631. doi:10.2307/1244569. 
Central Bureau of Statistics. (1988). Internal migration - Part A: Population by residence in 1983 and 1978, (Data from the sample enumeration). Jerusalem: CBS.

Central Bureau of Statistics. (various years). Statistical abstract of Israel. Jerusalem: CBS.

Champion, T., Coombes, M., and Brown, D.L. (2009). Migration and longer distance commuting in rural England. Regional Studies 43(10): 1245-1260. doi:10.1080/ 00343400802070902.

Champion, T. and Hugo, G. (eds.). (2003). New forms of urbanization: Beyond the urban-rural dichotomy. London: Ashgate.

Champion, T. and Sheppard, J. (2006). Demographic change in rural England. In: Lowe, P. and Speakman, L. (eds.). Older population of rural England. London: Age Concern: 21-40.

Choshen, M. (2008). Jerusalem's population: Changing Processes. In: Ahimeir, O. and Bar-Siman-Tov, Y. (eds.). Forty years in Jerusalem 1967-2007 [in Hebrew]. Jerusalem: The Jerusalem Institute for Israel Studies: 15-40.

Cohen, E. (1970). The city in the Zionist ideology. Jerusalem: Institute for Urban and Regional Studies, Hebrew University of Jerusalem.

Cromartie, J. and Parker, T. (2014). Population shifts across nonmetropolitan regions. In: Bailey, C., Jensen, L., and Ransom, E. (eds.). Rural America in a globalizing world. Morgantown: West Virginia University Press: 330-347.

Crowley, M. and Ebert, K. (2014). New rural immigrant destinations: Research for the 2010s. In: Bailey, C., Jensen, L., and Ransom, E. (eds.). Rural America in a globalizing world. Morgantown: West Virginia University Press: 401-420.

DellaPergola, S. (2008). World Jewish population, 2008. American Jewish Year Book 108: 569-620.

Domina, T. (2006). What clean break? Education and nonmetropolitan migration patterns, 1989-2004. Rural Sociology 71(3): 373-398. doi:10.1526/0036011067 78070626.

Eisenstadt, S.N. (1973). Israeli society: Background, development, problems [in Hebrew]. Jerusalem: Magnes Press. 
Frey, W.H. (1988). Migration and metropolitan decline in developed countries: A comparative study. Population and Development Review 14(4): 595-628. doi:10.2307/1973626.

Fuguitt, G., Brown, D.L., and Beale, C. (1989). Rural and small town America. New York: Russell Sage Foundation.

Fuguitt, G.V. and Brown, D.L. (1990). Residential preferences and population redistribution 1972-1988. Demography 27(4): 589-600. doi:10.2307/2061572.

Fulton, J.A., Fuguitt, G.V., and Gibson, R.M. (1997). Recent changes in metropolitannonmetropolitan migration streams. Rural Sociology 62(3): 363-384. doi:10.1111/j.1549-0831.1997.tb00656.x.

Glasgow, N. (1995). Retirement migration and the utilization of services in nonmetropolitan counties. Rural Sociology 60(2): 224-243. doi:10.1111/j.15490831.1995.tb00570.x.

Goldscheider, C. (1992). Demographic transformation in Israel: Emerging themes in comparative context. In: Goldscheider, C. (ed.). Population \& social change in Israel. Boulder, CO: Westview Press: 1-38.

Goldscheider, C. (2002). Israel's changing society: Population, ethnicity, \& development. Boulder, CO: Westview Press.

Gonen, A. (1998). Settlement of the immigrants: Geographic patterns. In: Sicron, M. and Leshem, E. (eds.). Profile of immigration wave: The absorption process of immigrants from the Former Soviet Union, 1990-1995 [in Hebrew]. Jerusalem: The Magnes Press: 232-269.

Green, G.P. (2001). Amenities and community economic development: Strategies for sustainability. Journal of Regional Analysis and Policy 31(2): 61-75.

Greenwood, M.J. (1985). Human migration: Theory, models, and empirical studies. Journal of Regional Science 25(4): 521-544. doi:10.1111/j.1467-9787.1985. tb00321.x.

Jensen, L. (2006). New immigrant settlements in rural America: Problems, prospects, and policies. Durham: University of New Hampshire, Carsey Institute. (Reports on Rural America, Vol. 1, Number 3).

Johnson, K.M. and Stewart, S.I. (2011). Recreation amenity migration and urban proximity. In: Green, G.P., Marcouiller, D., and Deller, S. (eds.). Amenities and rural development: Theory, methods, and public policy. Cheltenham, UK: Edward Elgar: 177-196. 
Kandel, W. and Brown, D.L. (eds.). (2006). Population change and rural society. Dordrecht: Springer. doi:10.1007/1-4020-3902-6.

Kandel W.A. and Parrado, E.A. (2005). Restructuring of the US meat processing industry and new Hispanic migrant destinations. Population Development Review 31(3): 447-471. doi:10.1111/j.1728-4457.2005.00079.x.

Kaplan, S. and Salamon, H. (2004). Ethiopian Jews in Israel: A part of the people or apart from the people? In: Rebhun, U. and Waxman, C.I. (eds.). Jews in Israel: Contemporary social and cultural patterns. Hanover and London: Brandeis University Press/University Press of New England: 118-148.

Khamaisi, R. (2005). Urbanization and urbanism of Arab localities in Israel [in Hebrew]. Horizons in Geography 64/65: 293-310.

Kirschenbaum, A. (1982). The impact of new towns in rural regions on population redistribution in Israel. Rural Sociology 47(4): 692-704.

Kirschenbaum, A. (1992). Migration and urbanization: Patterns of population redistribution and urban growth. In: Goldscheider, C. (ed.). Population \& social change in Israel. Boulder, CO: Westview Press: 65-88.

Kritz, M.M., Gurak, D.T., and Lee, M. (2011). Will they stay? Foreign-born outmigration from new U.S. destinations. Population Research Policy Review 30(4): 537-567. doi:10.1007/s11113-010-9200-3.

Kritz, M.M. and Nogle, J. (1994). Nativity concentration and internal migration among the foreign-born. Demography 31(3): 509-524. doi:10.2307/2061755.

Kulcsar, L.J. and Curtis, K. (eds.). (2012). The international handbook of rural demography. Dordrecht: Springer. doi:10.1007/978-94-007-1842-5.

Lacour, C. and Puissant, S. (2007). Re-urbanity: Urbanising the rural and ruralising the urban. Environment and Planning A 39(3): 728-747. doi:10.1068/a37366.

Lichter, D.T. and Brown, D.L. (2014). The new rural-urban interface: Lessons for higher education. Choices Magazine 29(1): 1-5.

Lichter, D.T. and Brown, D.L. (2011). Rural America in an urban society: Changing spatial and social boundaries. Annual Review of Sociology 37(1): 565-592. doi:10.1146/annurev-soc-081309-150208.

Molloy, R., Smith, C., and Wozniak, A. (2011). Internal migration in the US. Finance and economics. Washington, DC: Federal Reserve Bank. (Discussion Paper 2011-30). 
Newman, D. (2000). Internal migration in Israel: From periphery to center - from rural to urban. In: Elazar, D.J. and Weinfeld, M. (eds.). Still moving: Recent Jewish migration in comparative perspective. New Brunswick and London: Transaction Publishers: 205-226.

Rebhun, U. and Waxman, C.I. (2000). The 'Americanization' of Israel: A demographic, cultural and political evaluation. Israel Studies 5(1): 65-91. doi:10.2979/ isr.2000.5.1.65.

Shefer, D., Frenkel, A., and Roper, S. (2001). Innovation and plant characteristics of high-technology firms in Israel and Ireland. In: Felstein, D., McQuaid, R., McCann, P., and Shefer, D. (eds.). Public investment and regional economic development. Cheltenham and Northampton: Edward Elgar: 109-119.

Sicron, M. (1998). Demography of the wave of immigration. In: Sicron, M. and Leshem, E. (eds.). Profile of immigration wave: The absorption process of immigrants from the Former Soviet Union, 1990-1995 [in Hebrew]. Jerusalem: The Magnes Press: 13-40.

Sicron, M. (2004). Demography: Israel's population-characteristics and trends [in Hebrew]. Jerusalem: Carmel.

Vining, D.R., Pallone, R., and Yang, C.H. (1982). Population dispersal from core regions: A description and tentative explanation of the patterns in 20 countries. In: Kawashima T. and Kocelli, P. (eds.). Human settlement systems: Spatial patterns and trends. Laxenburg, Austria: International Institute for Applied Systems Analysis: 171-192.

Vining, D. and Strauss, A. (1977). A demonstration that the current deconcentration of population in the United States is a clean break with the past. Environment and Planning A 9(7): 751-758. doi:10.1068/a090751.

Wardwell, J.M. (1980). Toward a theory of urban-rural migration in the developed world. In: Brown, D.L. and Wardwell, J.M. (eds.). New directions in urbanrural migration. New York: Academic Press: 71-114. doi:10.1016/B978-0-12136380-2.50012-7.

Warren, R.L. (1987). The community in America. Washington, DC: University Press of America.

Zuiches, J.J. (1980). Residential preferences in migration theory. In: Brown, D.L. and Wardwell, J.M. (eds.). New directions in urban-rural migration. New York: Academic Press: 163-188. doi:10.1016/B978-0-12-136380-2.50015-2. 


\section{Appendix A}

\section{Table A1: Definitions and summary statistics for analysis variables}

\begin{tabular}{|c|c|c|}
\hline Variable & Definition & Mean \\
\hline \multicolumn{3}{|l|}{ Dependent Variables } \\
\hline \multicolumn{3}{|l|}{ Migration Status (M) } \\
\hline Urban-Rural & $=1$ for five-year migration from urban locality to rural locality & .188 \\
\hline Rural-Urban & $=0$ for five-year migration from rural locality to urban locality (reference) & .071 \\
\hline Between Similar Types & $=1$ for five-year migration from urban-to-urban or from rural-to-rural localities & .741 \\
\hline \multicolumn{3}{|l|}{ Individual Characteristics } \\
\hline \multicolumn{3}{|l|}{ Age (A) } \\
\hline $25-34$ & $=1$ for $25-34$ years old & .534 \\
\hline $35-44$ & $=1$ for $35-44$ years old & .265 \\
\hline $45-64$ & $=1$ for $45-64$ years old & .172 \\
\hline 65 and over & $=0$ for 65 years old + (reference) & .003 \\
\hline \multicolumn{3}{|l|}{ Gender (G) } \\
\hline Female & $=1$ for female & .515 \\
\hline Male & $=0$ for male (reference) & .485 \\
\hline \multicolumn{3}{|l|}{ Marital Status (S) } \\
\hline Single & $=1$ for single persons & .241 \\
\hline Divorced/Separated & $=1$ for divorced or separated persons & .120 \\
\hline Widowed & $=1$ for widowed & .017 \\
\hline Married & $=0$ for married persons (reference) & .622 \\
\hline \multicolumn{3}{|l|}{ Years in Israel $(Y)$} \\
\hline Foreign born 0-5 years in Israel & $=1$ for foreign-born with 5 or less years of residence in 2003 & .025 \\
\hline Foreign born $6-10$ years in Israel & $=1$ for foreign-born with 6 to 10 years of residence in 2003 & .041 \\
\hline Foreign born $11+$ years in Israel & $=1$ for foreign-born with $11+$ years of residence in 2003 & .149 \\
\hline Native born Israelis & $=0$ for persons born in Israel (reference) & .785 \\
\hline \multicolumn{3}{|l|}{ Ethnicity (E) } \\
\hline Ethnicity Europe-America & $=1$ for persons of European-American background & .349 \\
\hline Ethnicity Asia-Africa & $=1$ for persons of Asian-African background & .346 \\
\hline Ethnicity Israel-Israel & $=0$ for persons born in Israel whose fathers were also born in Israel (reference) & .305 \\
\hline \multicolumn{3}{|c|}{ 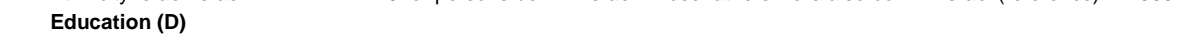 } \\
\hline Less than high school & $=0$ for less than high school (reference) & .042 \\
\hline High school no matriculation & $=1$ for high school graduation with no matriculation & .127 \\
\hline High school with matriculation & $=1$ for high school with matriculation exams & .195 \\
\hline Vocational & $=1$ for vocational studies & .146 \\
\hline B. A. degree & $=1$ for B.A. diploma & .340 \\
\hline M.A. degree or higher & $=1$ for M.A. or higher diploma & .150 \\
\hline \multicolumn{3}{|l|}{ Working Status (W) } \\
\hline Employee & $=0$ for employee (reference) & .911 \\
\hline Self-employed & $=1$ for self-employed & .089 \\
\hline \multicolumn{3}{|l|}{ Migration Distance (L) } \\
\hline Intra-district migration & $=0$ for migration within same districts (reference) & .437 \\
\hline $\begin{array}{l}\text { Inter-district migration } \\
\text { Income (I) }\end{array}$ & $=1$ for migration between districts & .563 \\
\hline Income quintile I & $=0$ for lowest quintile (0-19.9\%) (reference) & .276 \\
\hline Income quintile II & $=1$ for second quintile of income (20-39.9\%) & .230 \\
\hline Income quintile III & $=1$ for third quintile of income $(40-59.9 \%)$ & .194 \\
\hline Income quintile IV & $=1$ for forth quintile Of income $(60-79.9 \%)$ & .158 \\
\hline Income quintile $\mathrm{V}$ & $=1$ for fifth quintile Of income $(80-100 \%)$ & .142 \\
\hline
\end{tabular}


Rebhun \& Brown: Patterns and selectivities of urban/rural migration in Israel 